\title{
Salinization Processes in the Benichab Coastal Aquifer-Mauritania
}

\author{
Mouhamed Lemine Mohamed1,2, Djim M. L. Diongue'2, Huguette C. Emvoutou ${ }^{3}$, \\ Ahmed Salem Mohamed4, Mohamed Jiddou ${ }^{5}$, Serigne Faye ${ }^{2 *}$ \\ ${ }^{1}$ Tasiast Mauritanie Limited S. A. \& Site Service Department, Tasiast, Mauritania \\ ${ }^{2}$ Geology Department, University Cheikh Anta Diop, Dakar, Senegal \\ ${ }^{3}$ Earth Sciences Department, University of Douala, Douala, Cameroon \\ ${ }^{4}$ Polytehnic High School of Nouakchott, Nouakchott, Mauritania \\ ${ }^{5}$ Department of Geology, University of Nouakchott Al Aasriya, Nouakchott, Mauritania \\ Email: *serigne.faye@ucad.edu.sn
}

How to cite this paper: Mohamed, M.L., Diongue, D.M.L., Emvoutou, H.C., Mohamed, A.S., Jiddou, M. and Faye, S. (2020) Salinization Processes in the Benichab Coastal Aquifer-Mauritania. International Journal of Geosciences, 11, 377-392. https://doi.org/10.4236/ijg.2020.116020

Received: May 6, 2020

Accepted: June 6, 2020

Published: June 9, 2020

Copyright (c) 2020 by author(s) and Scientific Research Publishing Inc. This work is licensed under the Creative Commons Attribution International License (CC BY 4.0).

http://creativecommons.org/licenses/by/4.0/ Open Access

\begin{abstract}
A comprehensive and detailed study was conducted for the first time in the Benichab Region (western part of Mauritania) unique groundwater resource to identify the main process driving groundwater salinization using major and minor ions together with environmental isotopes. One hundred and nineteen samples were collected from 45 points (dug-wells and boreholes) during the period 2015 to 2017, where physico-chemical, chemical and isotope parameters were analyzed. $\mathrm{pH}$ values indicate circumneutral to basic (6.8 to 8.6) values while Electric Conductivity (EC) values show an increasing gradient from fresh groundwater lense $(\mathrm{EC}<1 \mathrm{mS} / \mathrm{cm})$ to highly saline groundwater in the vicinity of the Atlantic Ocean. In addition, TDS values range from 140 to $38,613 \mathrm{mg} / \mathrm{l}$. Geogenic inputs reveal water rock interactions dominated by ion exchange, dissolution-precipitation processes and evaporation. Minor ions such as $\mathrm{Br}$ and $\mathrm{B}$ indicate that the salinization of groundwater in the study area comes from mixing between seawater through salt sea intrusion and fresh water where sea water represents a mean value of $8.42 \%$. However, this marine source could increase with anthropogenic actions. According to $\delta$-values, the mean values range for rainfall, from $-3.8 \%$ and $-25.04 \%$ for $\delta^{88} \mathrm{O}$ and $\delta^{8} \mathrm{H}$, respectively; and for groundwater from $-5.0 \%$ and $-41.44 \%$ for $\delta^{18} \mathrm{O}$ and $\delta^{2} \mathrm{H}$ respectively. The isotopic characterization indicates fractionation processes such as evaporation and mixing of groundwater and seawater prevail in the unique source of potable water.
\end{abstract}

\section{Keywords}

Benichab, Salinization, Isotopes, Seawater 


\section{Introduction}

Groundwater salinization is one of the main issues threatening the sustainable groundwater development in coastal regions. Its occurrence in many coastal aquifers shows a complex pattern, resulting not only from current processes but also from past events, including sea-level fluctuation, subsidence, climate change, mixing and human activity [1]. Different origins of groundwater salinization have been suggested through intensive research during the recent years: 1) actual seawater intrusion due to intense aquifer exploitation and/or sea level rise [2] [3] [4]; 2) mobilization of saline paleowaters due to past transgressions [5] [6]; 3) water-rock interaction like evaporite dissolution [7] [8]; 4) upcoming of saltwater from deep and adjacent reservoirs [9] [10] [11]; 5) anthropogenic contamination like return flow [12] [13] [14] [15] and most often; 6) a combination of some of these processes [10] [16].

Benichab region is under arid climate located in the coastal western part of the Mauritanian sedimentary basin. The region which is experienced a growing population and socio-economic development due to mining activities is facing an increasing water demand for domestic, pastoral, mining and socioeconomic development for this unique groundwater resource. Therefore, groundwater is being overexploited for drinking water and mining activities for this none renewable freshwater lense being affected by high salinity along its coastal fringeand relic of brine to brackish water identified in some deep boreholes whose origin has never been investigated. Works carried out in this system besides that made by Tasiast gold mine which data are used here are limited mainly to geophysical investigations for boreholes implementation.

The main objective of this paper is to characterize the geochemical processes associated to groundwater salinization in Benichab aquifer. Therefore, through the determination of major and minor ions and isotopic contents, we intend specifically to: 1) characterize the salinity distribution of groundwater 2) to identify the mechanism(s) of groundwater salinization.

Salinization processes can be diagnosed using many techniques such as geochemical and/or isotopic tools. As the useful indicators, $\mathrm{Cl} / \mathrm{Br}$ molar ratio and stable isotope have been widely used to demonstrate the origin and transport processes of solutes in groundwater [17] [18]. Usually, major and minor elements concentrations such as $\mathrm{Sr}$ and $\mathrm{Br}$ can be used to identify origins of aquifer water salinization due to single process [2] [19]. Chloride concentrations and $\mathrm{Cl} / \mathrm{Br}$ ratios are used to determine the sources of salinity, especially when seawater intrusion occurs [20]. When groundwater salinization results from a combination of several processes, environmental stable isotopes $\left(\delta^{8} \mathrm{O}\right.$ and $\left.\delta^{2} \mathrm{H}\right)$ are more efficient to identify origins of saline groundwater [21].

\section{Study Area}

\subsection{Description of the Study Area}

The study area is located between $18^{\circ}$ and $20^{\circ} \mathrm{N}, 15^{\circ}$ and $16^{\circ} \mathrm{W}$, covering the 
NW part of Mauritania and an area of approximately $7900 \mathrm{~km}^{2}$. Benichab is the main city in the study area, and it is located in the south of the big city of Nouadhibou (Figure 1).

The climate in north-western Mauritania is arid with high evaporation rate and low rainfall amount. Nevertheless, some regional difference exists, with the highest mean annual rainfall $(87 \mathrm{~m})$ in the southern part of the area and lowest rainfall in the northern part $(25 \mathrm{~mm})$. With such a low rainfall amount and high potential evaporation of nearly $3700 \mathrm{~mm} /$ year, the groundwater recharge can only occur at favorable sites. The temperature ranges from $28^{\circ} \mathrm{C}$ in January to $42^{\circ} \mathrm{C}$ in June.

The topography of the study area is characterized by moderate relief composed mostly of Ogolian dunes (20,000 to 12,000 years BP) separated by inter-dune channels known locally as "gouds".

The economic activities of the population are based on extensive livestock farming, traditional sea fishing and gold artisanal exploitation. Also, mining companies occupy an important place in the economy of this region with $\mathrm{Ki}$ nross (gold) and MCM (copper and gold) establishment since 2017.

\subsection{Geology and Hydrogeology Framework}

The Benichab region belongs to the large Senegal-Mauritanian basin. The local geology consists of a succession of sedimentary series of marine, fluvial and aeolian origin, from the Meso-Cenozoic to Quaternary age [22] [23] [24] [25]. These sedimentary formations cover the basement rock that outcrops in the eastern and northern part of the region. During the Quaternary, the region experienced several marine transgressions. The most recent was the transgressive period of the Nouakchottian [26], which may be the source of the groundwater

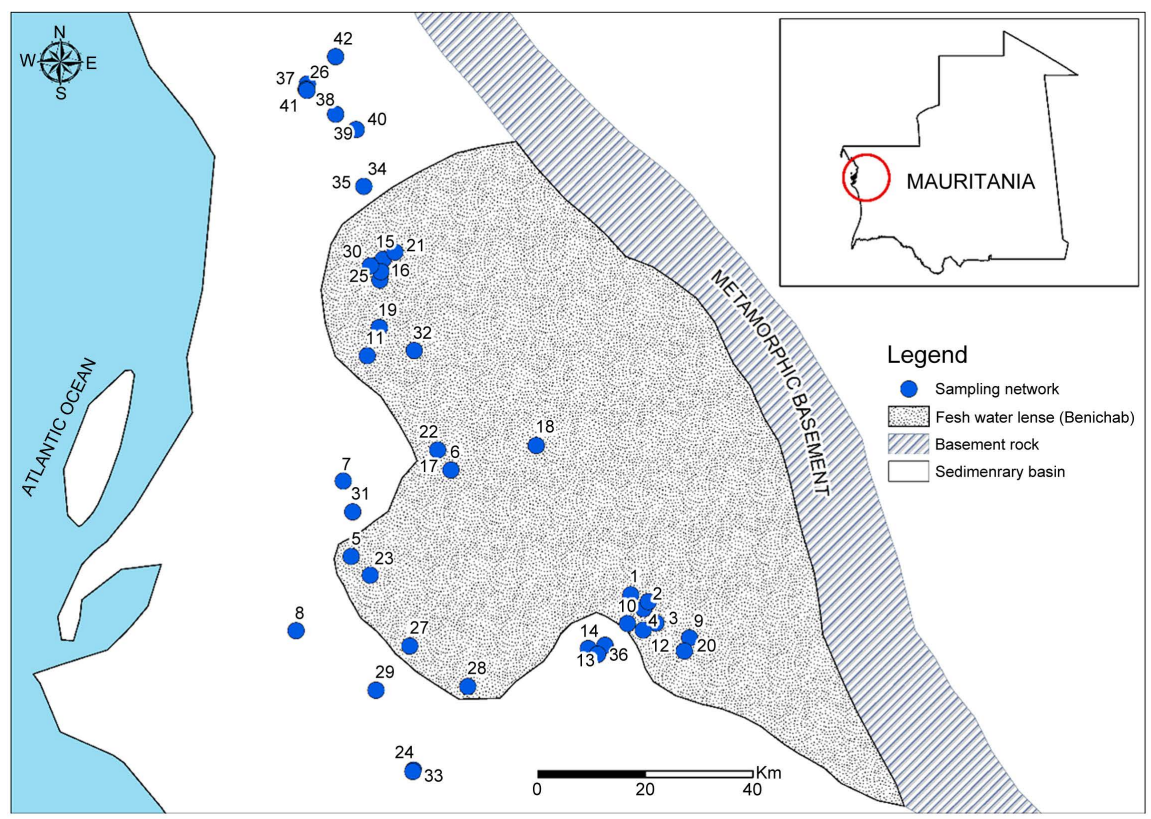

Figure 1. Location of the study area and sampling network. 
salinity. A geological cross section established using the hydraulic boreholes data shows the configuration of the aquifer in the study area (Figure 2) made of Continental Terminal (CT) formations which are detritic materials with discontinuous interbedded sandstone, sandy clay, clayey sand, sandy lenses and clay. They constitute an unconfined aquifer which sediments are heterogeneous both laterally and vertically. The groundwater level monitoring since 2015 show no significant seasonal variation and flow direction is mainly from the northwest to the southeast precisely from the Atlantic Ocean to the continent.

\section{Sampling Analysis}

Groundwater was collected from 45 sampling points composed of dug-wells and boreholes during 4 campaigns (wet and dry season) from 2015 to 2017 (Figure 3). Water table depth, Temperature, $\mathrm{pH}$, electric conductivity and salinity were measured using a portable meter (WTW device) in the field. Water samples were taken after purging the wells until constant value of conductivity obtained. Groundwater samples for chemical analyses were filtered and samples for cation analyses were acidified to $\mathrm{pH}<2$ with $\mathrm{HCl}$. All collected samples were stored at $5^{\circ} \mathrm{C}$ until analyses. Major and minor elements were analyzed at the $\mathrm{Al}$ control Laboratory in UK through various procedures: ICP-MS for $\mathrm{Ca}, \mathrm{Na}, \mathrm{Mg}, \mathrm{Fe}, \mathrm{K}, \mathrm{B}$ and Sr; spectrophotometry for $\mathrm{SO}_{4}, \mathrm{Cl}$ and $\mathrm{NO}_{3}$; chromatography for $\mathrm{Br}$. The analysis of the stable isotopes was carried out at the Sfax (Tunisia) and Avignon (France) laboratories. Results were expressed relative to the international standards (V-SMOW for $\delta^{18} \mathrm{O}$ and $\delta^{2} \mathrm{H}$ ) in \%. The analytical uncertainties were $\pm 0.3 \%$ o $\delta^{8} \mathrm{O}$ and $\pm 2 \%$ ofor $\delta^{2} \mathrm{H}$.

\section{Results}

\subsection{Salinity Distribution and Water Type}

Statistics of physico-chemical parameters and chemical composition of 119

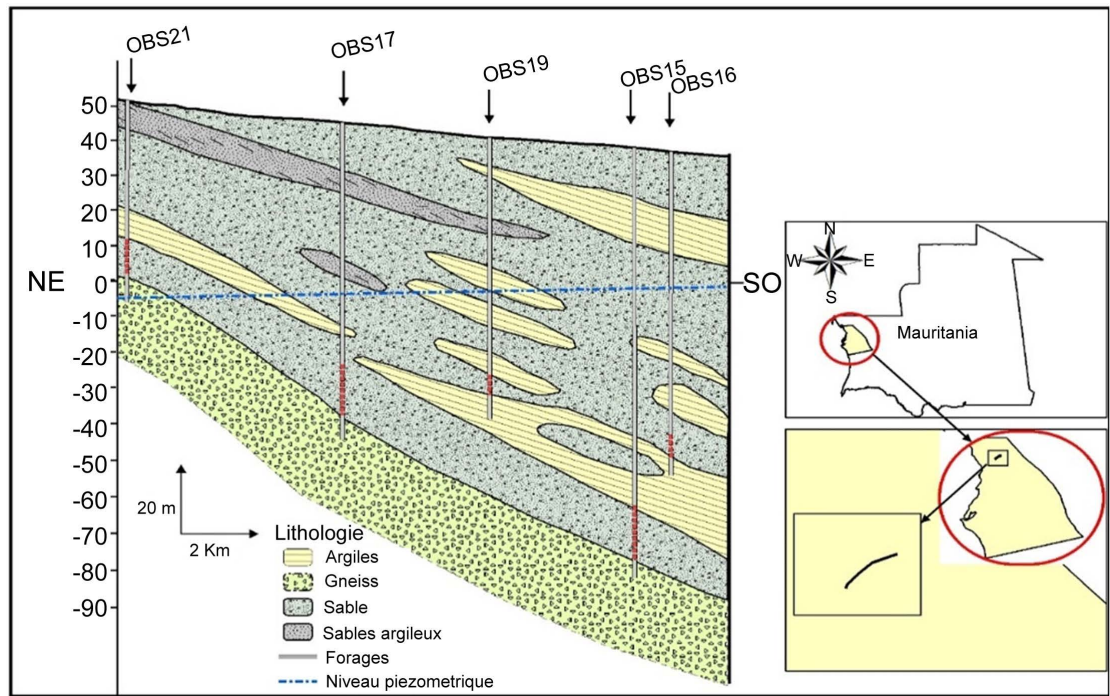

Figure 2. Hydrogeological setting. 


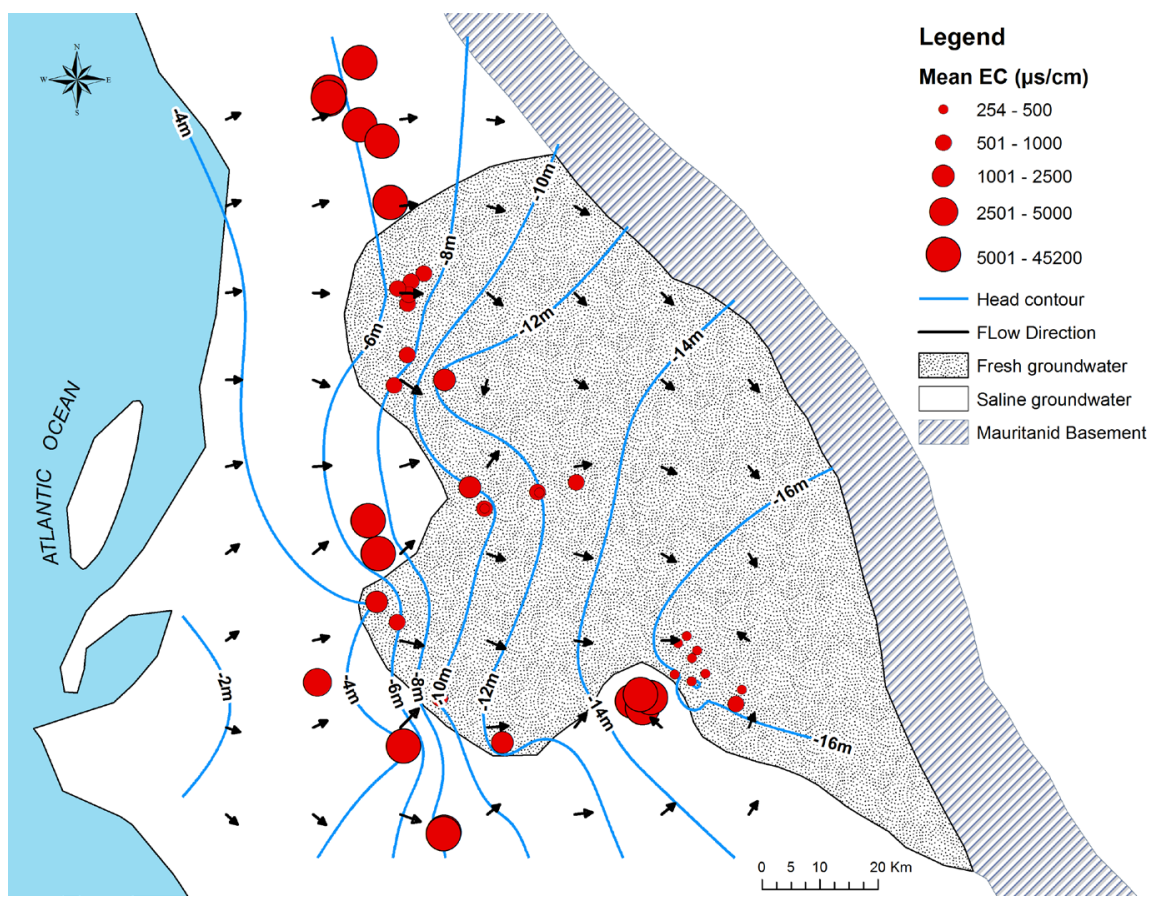

Figure 3. Piezometric map and EC distribution (mean value of all campaigns).

groundwater samples through 4 field campaigns during 2015-2017 are shown in Table 1. The water samples exhibit $\mathrm{pH}$ values circumneutral to basic (6.8 to 8.6) and TDS values calculated from EC ranging from 140 to $38,613 \mathrm{mg} / \mathrm{L}$. The distribution of EC values shows a gradual increase from fresh groundwater lense (EC value $<1 \mathrm{mS} / \mathrm{cm}$ ) towards the Atlantic Ocean where the groundwater is highly saline (EC ranging from 25 to $45.5 \mathrm{mS} / \mathrm{cm}$ ). The most saline waters are observed in wells located in the north near the coastal area. This gradual pattern is evidenced by the groundwater flow mainly from the ocean to the aquifer (Figure 3) suggesting potential seawater intrusion.

Chemical data plotted to the Piper diagram [27] show different water types spatially distributed (Figure 4):

1) $\mathrm{m}-\mathrm{HCO}_{3}$ and $\mathrm{Na}-\mathrm{HCO}_{3}$, representing the fresh Groundwater lense;

2) $\mathrm{Na}-\mathrm{Cl}$ occurring in the coastal area represents the saline waters;

3) Na-m, m-Cl and mixed facies, a mixture type between fresh water and saline water. The gradation can be seen from $\mathrm{Na}-\mathrm{Cl}$ (saline water) and $\mathrm{m}-\mathrm{HCO}_{3}$ (fresh water), particularly in the cation triangle where the alignment is linear.

\subsection{Hydrogeochemical Process}

\subsubsection{Geochemical Process}

It is known that water chemistry depends on mixing of different water bodies and/or geochemical reactions such as dissolution-precipitation, evaporation, ion exchange processes. In order to discriminate about processes driving the chemical composition of groundwater, bivariate diagrams (ions/ $\mathrm{Cl}$ vs $\mathrm{Cl}$ ) are useful tools (Figure 5) to identify mixing mechanisms of fresh and saline groundwater from additional chemical reactions [2]. 


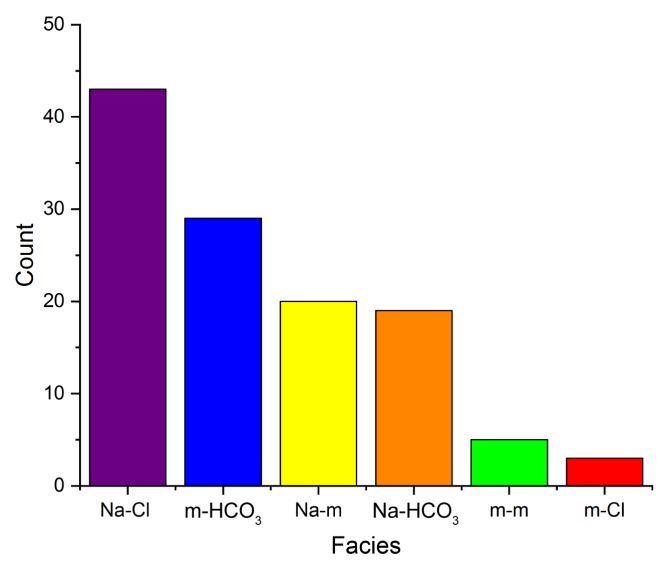

(a)

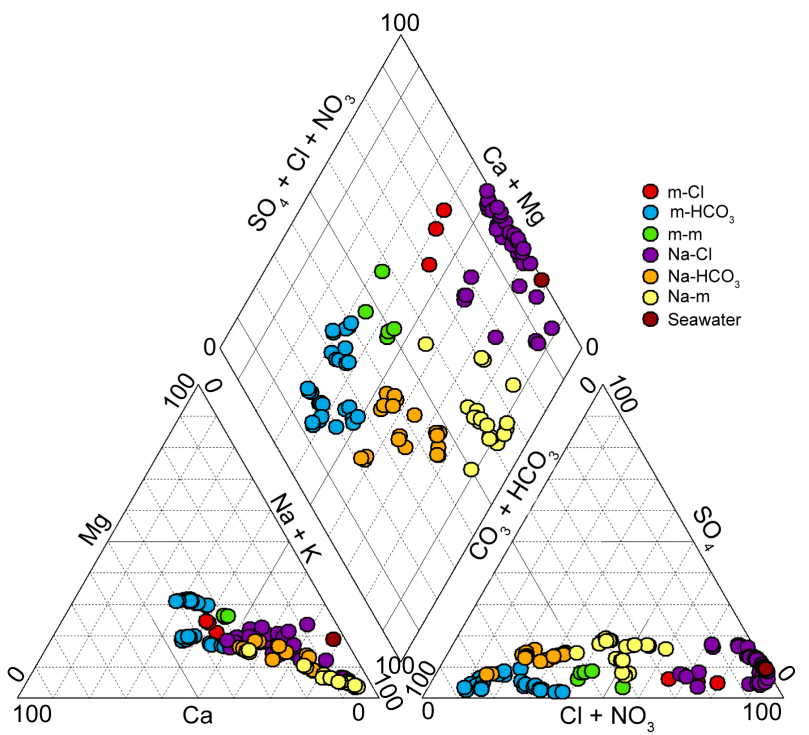

(b)
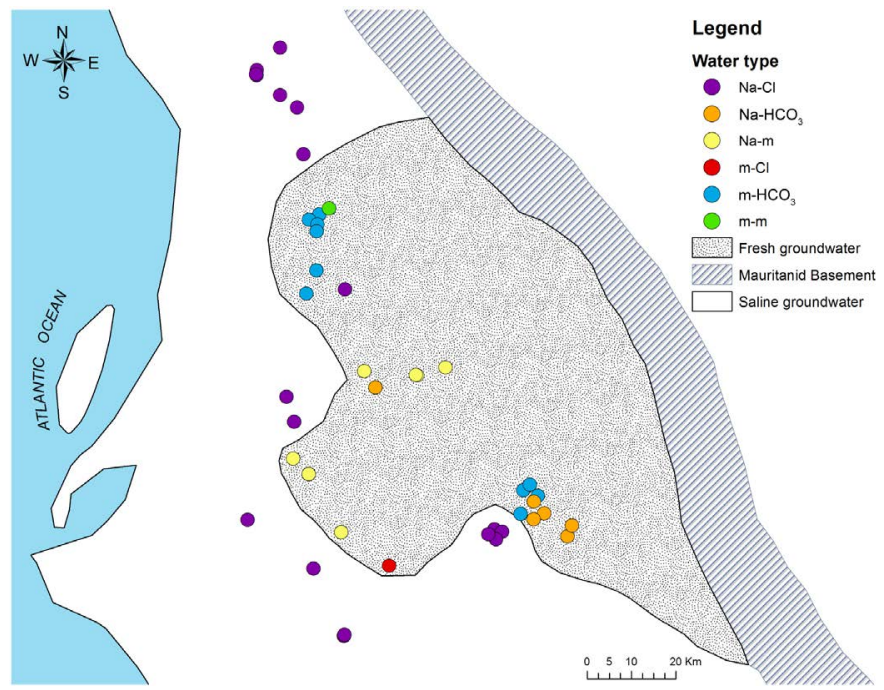

(c)

Figure 4. Water types [(a): Piper diagram of all samples; (b) Count plot of facies abundance; (c) Spatial distribution of facies (mean value of all campaigns)]. 


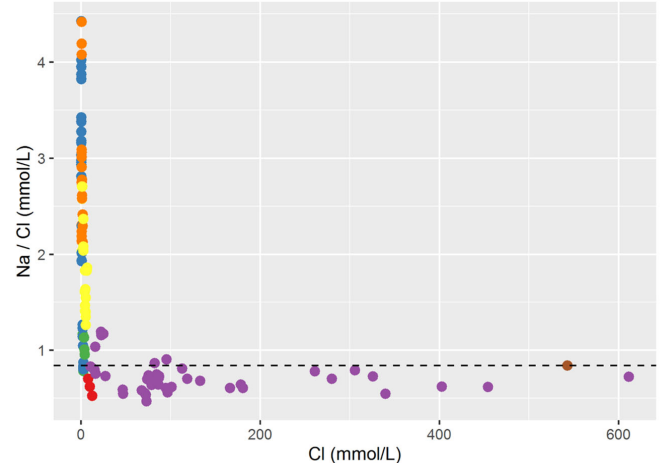

(a)

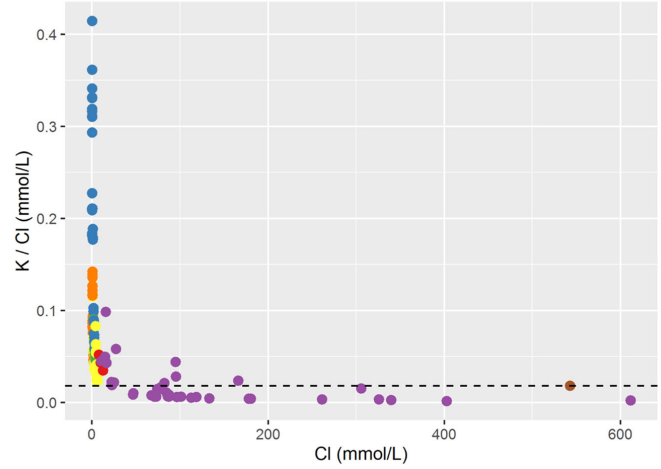

(c)

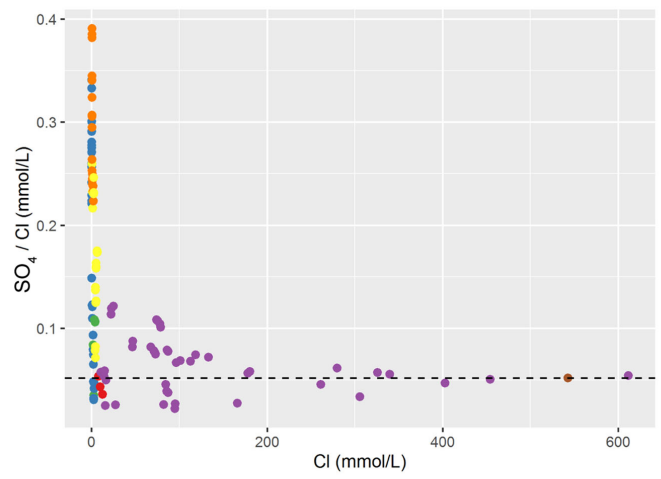

(e)

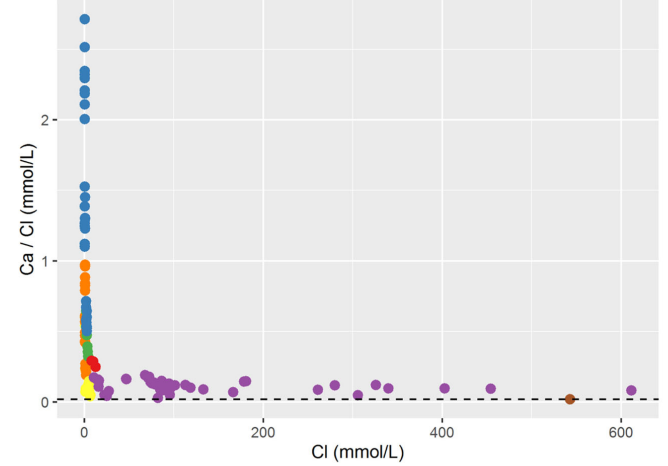

(b)

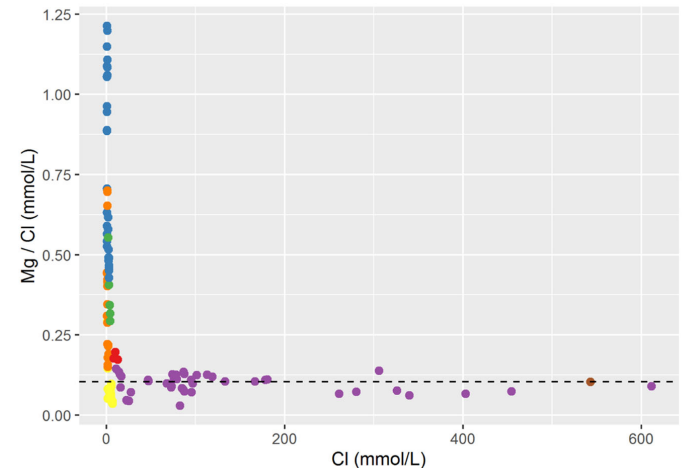

(d)

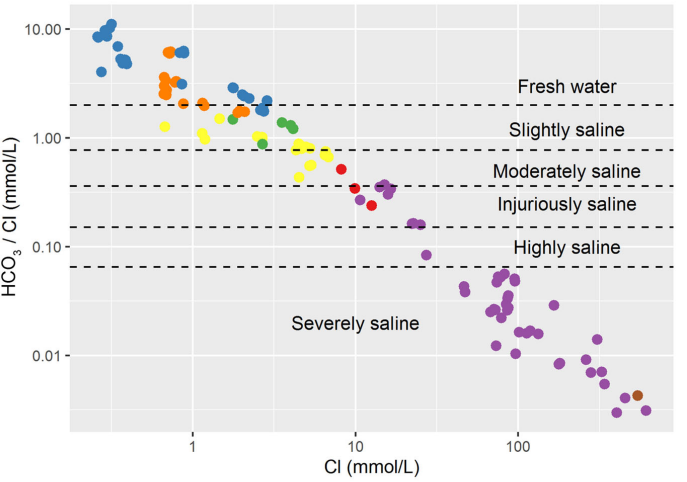

(f)

Figure 5. Bivariate plots of major ions relative to $\mathrm{Cl}$ vs $\mathrm{Cl}$ [(a) $\mathrm{Na} / \mathrm{Cl}$ vs $\mathrm{Cl}$; (b) $\mathrm{Ca} / \mathrm{Cl}$ vs $\mathrm{Cl}$; (c) $\mathrm{K} / \mathrm{Cl}$ vs $\mathrm{Cl} ;(\mathrm{d}) \mathrm{Mg} / \mathrm{Cl}$ vs $\mathrm{Cl}$; (e) $\mathrm{SO}_{4} / \mathrm{Cl}$ vs $\mathrm{Cl}$; (f) $\mathrm{HCO}_{3} / \mathrm{Cl}$ vs $\mathrm{Cl}$ )]. The legend is the same as in Figure 4.

In the lowest salinity group $\left(\mathrm{Na}-\mathrm{HCO}_{3}, \mathrm{~m}-\mathrm{HCO}_{3}, \mathrm{Na}-\mathrm{m}\right)$, the freshwater has high molar ratio while the saline group $(\mathrm{Na}-\mathrm{Cl})$ has molar ratio that are close or even below the value of sea water which is the main source of salinization. However, $\mathrm{Na}^{+}, \mathrm{K}^{+}, \mathrm{Mg}^{2+}, \mathrm{Ca}^{2+}$ and $\mathrm{SO}_{4}^{2-}$ relative to chloride molar ratios increase suggest some contributions of other processes occurring in the fresh water group such as hydrolysis of silicate minerals, ions exchange reaction, gypsum dissolution, calcite dissolution [28]. The relationship between $\mathrm{HCO}_{3} / \mathrm{Cl}$ ratios and $\mathrm{Cl}$ also exhibits a pronounced negative slope indicating the reverse relationship between carbonate (freshening) and $\mathrm{Cl}$ (salinization) [2] [29]. 
Table 1. Statistics values of physico-chemical parameters and chemical analysis.

\begin{tabular}{|c|c|c|c|c|c|c|c|}
\hline Parameters & unit & N Total & Min & Max & Mean & Median & $\mathrm{SD}$ \\
\hline $\mathrm{CE}$ & $\mu \mathrm{s} / \mathrm{cm}$ & 118 & 227 & 45200 & 4599.3 & 894.5 & 7801.7 \\
\hline TDS mg/l & $\mathrm{mg} / \mathrm{L}$ & 112 & 254.0 & $64,571.4$ & 6220.4 & 972.5 & $12,709.2$ \\
\hline $\mathrm{pH}$ & - & 105 & 6.8 & 8.6 & 7.6 & 7.6 & 0.4 \\
\hline $\mathrm{T}$ & ${ }^{\circ} \mathrm{C}$ & 101 & 21.1 & 36.7 & 29.9 & 30.2 & 2.7 \\
\hline $\mathrm{HCO}_{3}^{-}$ & $\mathrm{mg} / \mathrm{L}$ & 119 & 51.9 & 384.0 & 190.3 & 165.0 & 81.6 \\
\hline Cl- & $\mathrm{mg} / \mathrm{L}$ & 119 & 9.1 & $21,400.0$ & 1707.1 & 145.0 & 3517.3 \\
\hline $\mathrm{SO}_{4}^{2-}$ & $\mathrm{mg} / \mathrm{L}$ & 119 & 4.4 & 3190.0 & 278.9 & 42.5 & 513.9 \\
\hline $\mathrm{NO}_{3}^{-}$ & $\mathrm{mg} / \mathrm{L}$ & 119 & 0.0 & 142.0 & 10.9 & 6.2 & 18.6 \\
\hline $\mathrm{Ca}^{2+}$ & $\mathrm{mg} / \mathrm{L}$ & 119 & 3.5 & 2010.0 & 217.0 & 45.6 & 385.6 \\
\hline $\mathrm{Na}^{+}$ & $\mathrm{mg} / \mathrm{L}$ & 119 & 18.5 & $10,200.0$ & 796.4 & 132.0 & 1569.9 \\
\hline $\mathrm{Mg}^{2+}$ & $\mathrm{mg} / \mathrm{L}$ & 119 & 1.5 & 1330.0 & 112.3 & 24.0 & 210.4 \\
\hline $\mathrm{K}^{+}$ & $\mathrm{mg} / \mathrm{L}$ & 117 & 2.5 & 184.0 & 18.8 & 7.1 & 29.5 \\
\hline $\mathrm{Fe}$ & $\mathrm{mg} / \mathrm{L}$ & 119 & 0.0 & 2.5 & 0.1 & 0.0 & 0.3 \\
\hline $\mathrm{Br}^{-}$ & $\mu \mathrm{g} / \mathrm{L}$ & 108 & 0.0 & $36,800.0$ & 2894.1 & 290.0 & 5770.0 \\
\hline $\mathrm{F}^{-}$ & $\mu \mathrm{g} / \mathrm{L}$ & 108 & 0.0 & 1230.0 & 465.7 & 551.5 & 363.6 \\
\hline $\mathrm{Sr}^{-}$ & $\mu \mathrm{g} / \mathrm{L}$ & 109 & 70.9 & $37,200.0$ & 2057.1 & 867.0 & 4122.6 \\
\hline $\mathrm{B}^{-}$ & $\mu \mathrm{g} / \mathrm{L}$ & 110 & 58.5 & 778.0 & 228.6 & 185.5 & 138.4 \\
\hline
\end{tabular}

Based on the inverse of Simpson's ratio as reported by [30], the relative abundance of saline water can be itemized into six classes (Figure 5(f)). In general, a $\mathrm{HCO}_{3} / \mathrm{Cl}$ ratio $>2$ indicates freshwater whereas a ratio less than unity indicates higher degrees (or potential) of salinization [31]. Fresh waters include $\mathrm{Na}-\mathrm{HCO}_{3}$ and $\mathrm{m}-\mathrm{HCO}_{3}$ facies, slightly/moderate saline waters are Na-m and $\mathrm{m}-\mathrm{m}$ facies and saline waters are $\mathrm{Na}-\mathrm{Cl}$ and $\mathrm{m}-\mathrm{Cl}$. Severely saline waters are of $\mathrm{Na}-\mathrm{Cl}$ facies mostly located in the northern part of the study area.

To investigate the other potential sources of groundwater mineralization, different correlations were established between ions (Figure 6). Figure 6(a) shows in one hand, a positive correlation between $\mathrm{Ca}+\mathrm{Mg}$ and $\mathrm{HCO}_{3}+\mathrm{SO}_{4}$ close to [1:1] equilibrium line in the fresh water group indicating that the carbonate and sulphate minerals dissolution are involved in groundwater mineralization. In the other hand, the majority of saline samples are above the equilibrium line [1:1], which indicates the presence of inverse ionic exchange under seawater intrusion influence [32] [33]. This latter process is exhibited in the graph $[(\mathrm{Ca}+\mathrm{Mg})-$ $\left.\left(\mathrm{HCO}_{3}+\mathrm{SO}_{4}\right)\right]$ vs $[(\mathrm{Na}+\mathrm{K})-\mathrm{Cl}]$ (Figure 6(b)) by linear negative trend [34] [35].

In general, the increase in the concentration of $\mathrm{Sr}$ parallel to that of $\mathrm{Cl}$ ion is largely due to the saltwater. However, in water-rock interaction system, this process is not the only source of $\mathrm{Sr}$ in aqueous phase. A poor correlation between $\mathrm{Sr}$ and $\mathrm{Cl}$ in the saline groundwater group indicates an additional input of 


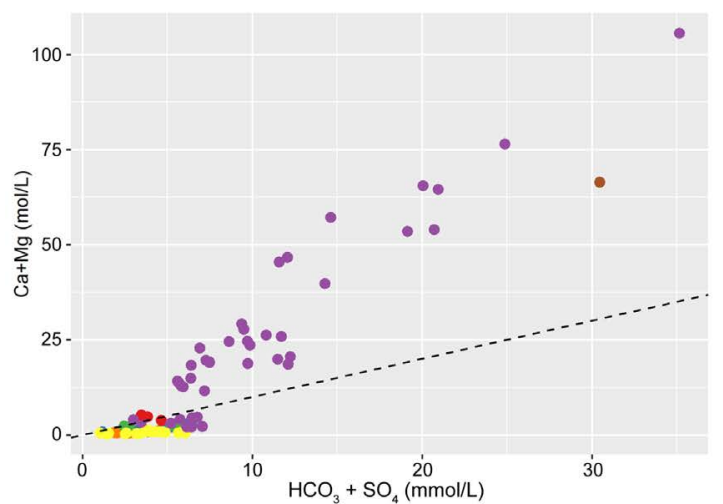

(a)

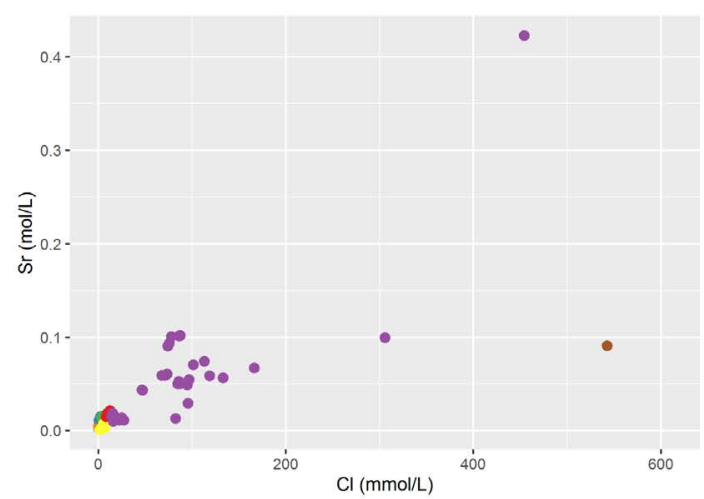

(c)

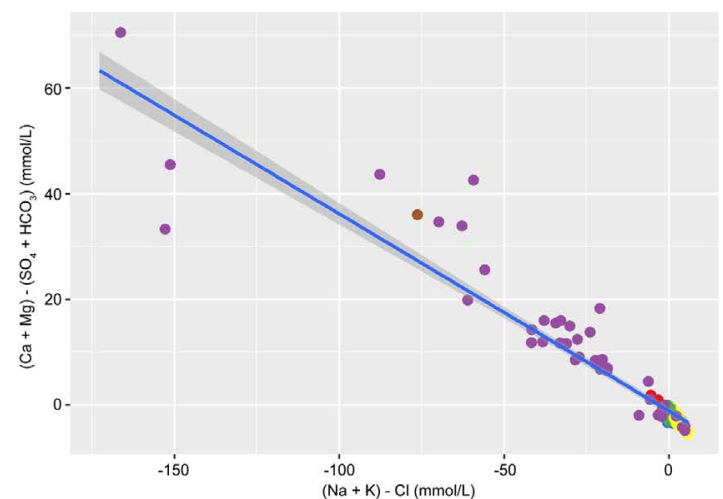

(b)

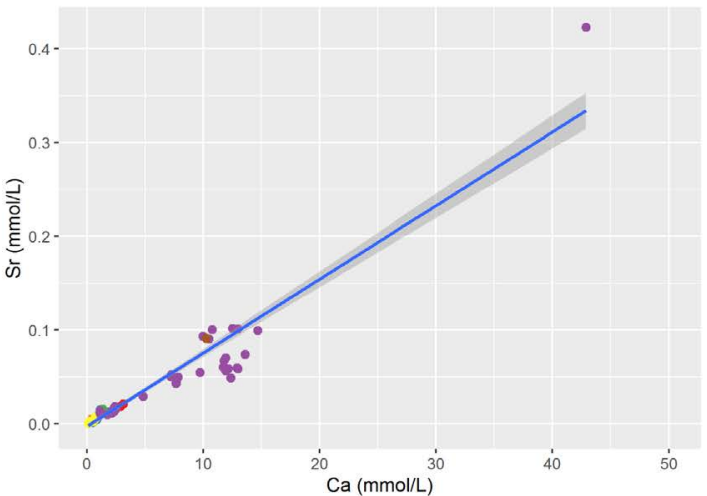

(d)

Figure 6. Bivariate plots exhibiting silicate weathering and ionic exchange $\left[(\mathrm{a}) \mathrm{Ca}+\mathrm{Mg}\right.$ vs $\mathrm{HCO}_{3}+\mathrm{SO}_{4} ;(\mathrm{b})(\mathrm{Ca}+\mathrm{Mg})-(\mathrm{HCO}+$ $\left.\mathrm{SO}_{4}\right)$ vs $(\mathrm{Na}+\mathrm{K})-\mathrm{Cl}$; (c) Sr vs $\mathrm{Cl}$; (d) Sr vs $\mathrm{Ca}$. The legend is the same as in Figure 4.

$\mathrm{Sr}$ [28]. Plots of Ca vs Sr (Figure 6(c)) show a linear correlation which indicates $\mathrm{Sr}$ input from carbonate dissolution or precipitation and gypsum. The mean $\mathrm{Ca} / \mathrm{Sr}$ molar ratios in groundwaters (141) exceed the seawater value (113) with highest values found in the fresh groundwater group (278). The lowest values found in the saline water group indicate concomitant reverse ion exchange where $\mathrm{Ca}$ is released and $\mathrm{Na}$ absorbed at clay minerals surface.

\subsubsection{Salinization}

Minor elements, such as $\mathrm{Br}$ and $\mathrm{B}$ can be valuable markers of fresh/seawater mixing. The $\mathrm{Br} / \mathrm{Cl}$ ratios have been used to distinguish salinity of marine and non-marine origins [36]. Because $\mathrm{Br}$ and $\mathrm{Cl}$ are relatively conservative in hydrological systems, the $\mathrm{Br} / \mathrm{Cl}$ ratios of fresh waters are primarily controlled by the initial ratio in precipitation. As sea salt spray is the primary source of these ions, precipitation should have a $\mathrm{Br} / \mathrm{Cl}$ ratio similar to that of seawater. Thus, the $\mathrm{Br} / \mathrm{Cl}$ ratio should be constant when salinization of fresh water occurs by simple mixing of seawater if there is no anthropogenic contamination [2].

On the bivariate plot of $\mathrm{Br} / \mathrm{Cl}$ ratios expressed in $\left[1000^{\star} \mathrm{Br} / \mathrm{CL}\right.$ ] vs $\mathrm{Cl}$ (Figure $7(\mathrm{a})$ ), as $\mathrm{Cl}$ concentration increases, the $\mathrm{Br} / \mathrm{Cl}$ ratios of saline groundwaters are maintained in the normal seawater range ( 0.7 to 2.0 ), indicating that the 


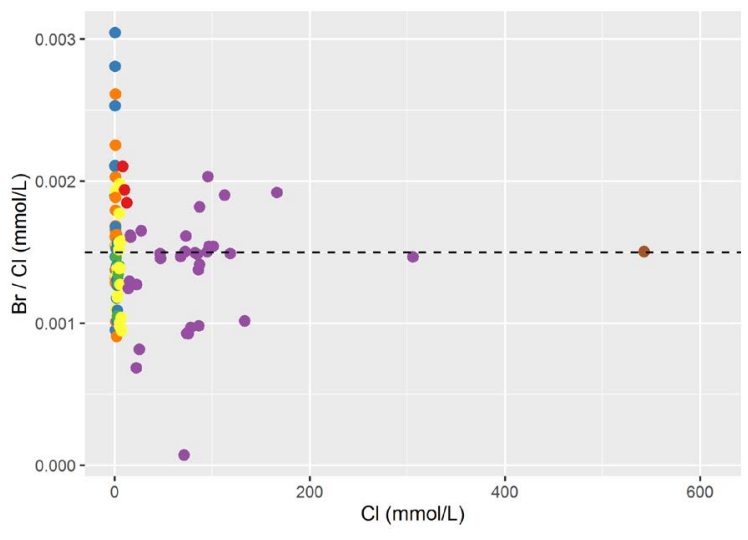

(a)

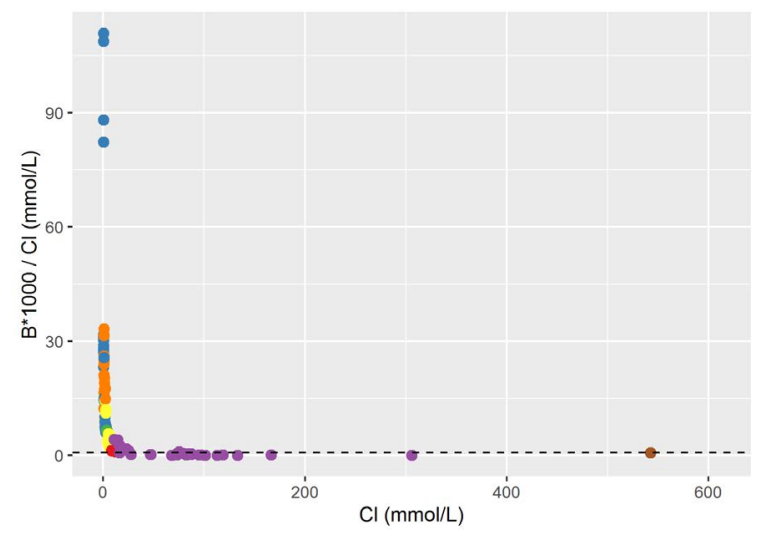

(b)

Figure 7. Bivariate plots of minor elements relative to $\mathrm{Cl}$ vs $\mathrm{Cl}\left[(\mathrm{a}) \mathrm{Br}^{\star} 1000 / \mathrm{Cl}\right.$ vs $\mathrm{Cl}$; (b) $\mathrm{B}^{\star} 1000 / \mathrm{Cl}$ vs $\left.\mathrm{Cl}\right]$. The legend is the same as in Figure 4.

salinization of these groundwaters results mainly from mixing precisely with seawater. The lowest $\mathrm{Br} / \mathrm{Cl}$ ratio (0.07) suggests a potential source of $\mathrm{Br}$, probably anthropogenic, other than seawater as evidenced by [37]. Moreover, $\mathrm{B} / \mathrm{Cl}$ ratios of all saline groundwaters are similar to the seawater ratio, suggesting that their salinities mainly result from seawater.

\subsubsection{Quantification of Seawater Intrusion}

The fraction of seawater $\left(f_{\mathrm{sw}}\right)$ was calculated from the $\mathrm{Cl}$ concentration. This latter is considered as conservative tracer not participating in the ion exchange process [38]. The ratio is calculated using Equation (1) [39]:

$$
f_{\text {sw }}=\left(\delta_{\text {sample }}-\delta_{\text {fresh }}\right) /\left(\delta_{\text {sea }}-\delta_{\text {fresh }}\right) \times 100
$$

With $\delta_{\text {sample }}$ as sample chloride concentration; $\delta_{\text {fresh }}$ as freshwater chloride concentration and $\delta_{\text {sea }}$ as seawater chloride concentration. The two end members of the mass balance equation represent the mean composition of the fresh groundwater adjacent to the saline front and the seawater composition, respectively.

The computed values of seawater contribution vary from $0 \%$ to $100 \%$ with a mean value of $8.42 \%$. As already classified with the Piper diagram, saline waters are represented mostly by $\mathrm{Na}-\mathrm{Cl}$ facies (Figure 8(a)). High mixing rates in $\mathrm{Na}-\mathrm{Cl}$ group in the box-plot (Figure $8(\mathrm{~b})$ ) are found in wells located in the northern part of the study area where $\mathrm{Cl}$ content can exceed the value of sea water due to high evaporation uptake. This is in agreement with groundwater flow direction which indicate inflow from the ocean towards the aquifer and the positive trend between $\mathrm{Cl}$ and $\mathrm{Br}\left(\mathrm{R}^{2}=0.9\right)$ suggesting marine source.

Beside the evidence of actual inflow from the ocean, sea level in coastal Benichab has fluctuated by approximately $1-3 \mathrm{~m}$ around its current elevation over the last six millennia (post-6000 Holocene) [25]. Therefore, the study area was regularly submerged by seawater. During the regression phases, part of the seawater was trapped inside the detrital deposits, and the different deposits have incorporated a significant amount of salts [40] [41]. In addition to this, the high 


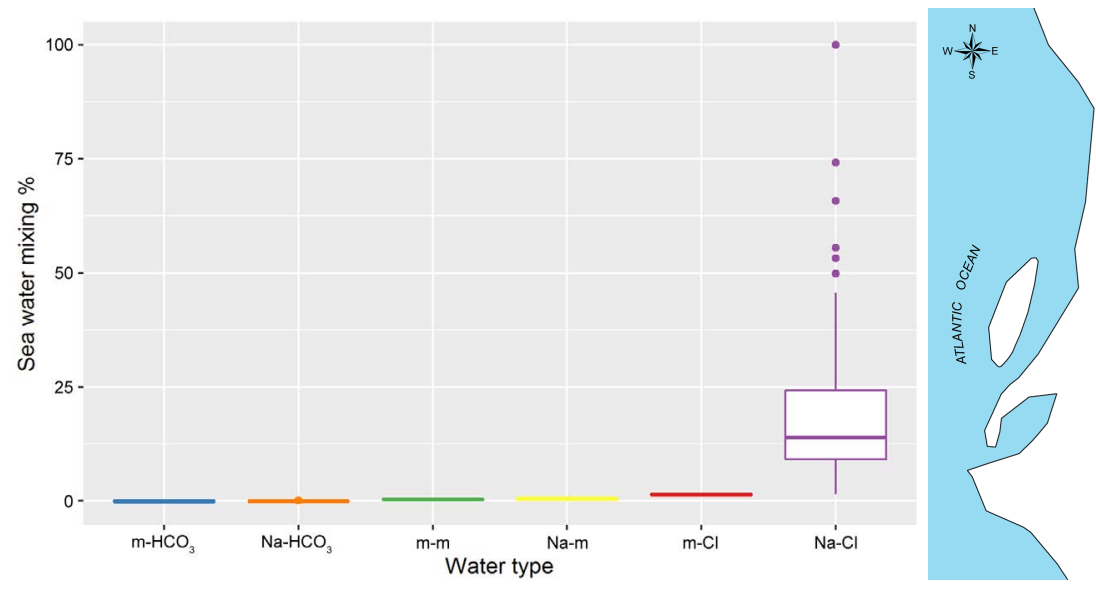

(a)

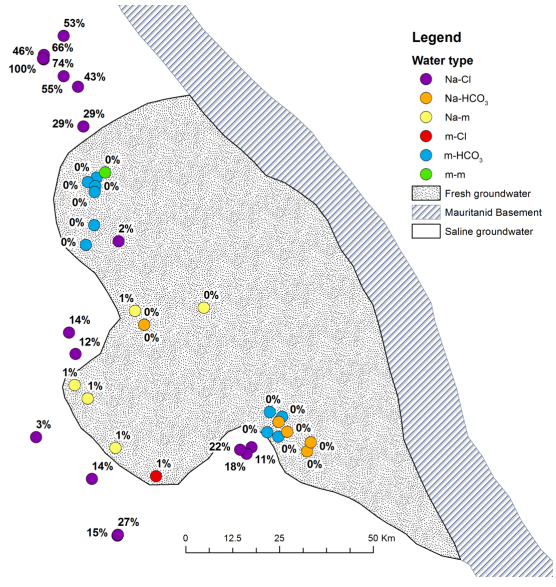

(b)

Figure 8. Seawater mixing [(a) Box plot water type vs seawater ratio; (b) Spatial distribution of seawater ratio (mean values of all campaigns)].

evaporation rate associated to the aridity of the study area and the low hydraulic gradients of the aquifer has produced these paleo-saline waters observed in the Northern part of Benichab (Figure 8(b)).

\subsection{Stable Isotope Geochemistry}

The stable isotopes of oxygen and hydrogen are generally considered to be transported conservatively in shallow aquifer settings, prevalence of high water-rock ratios and an absence of significant evaporation. Nevertheless, in the Benichab where temperature can reach $42^{\circ} \mathrm{C}$ (in June) as well as high evaporation $(3700 \mathrm{~mm} /$ year), it is likely that rainfall evaporates before and even after infiltration had occurred. Therefore, the values of the isotopic signature should be combined with the other finger-prints to evaluate the salinization processes [28].

The GNIP data from Louga station (Senegal), which is the closest to the study area, were used for isotopic characterization of precipitation. They range from $-6.0 \%$ to $-1.9 \%$ with a mean of $-3.8 \%$ for $\delta^{8} \mathrm{O}$; and $-42.69 \%$ to $-8.30 \%$ with a mean of $-25.04 \%$ for $\delta \mathrm{H}$. According to the Ordinary Least Square Regression (OLSR) method proposed by [42], the Local Meteoric Water Line (LMWL) defined by $\delta^{2} \mathrm{H}=(7.38 \pm 0.90)^{\star} \delta^{18} \mathrm{O}+(3.02 \pm 1.00)$ indicates values quite different from that of GMWL [43]; suggesting the occurrence of fractionation processes, particularly evaporation.

Isotopic compositions of the groundwater samples range from $-1.8 \%$ o to $-6.9 \%$ for $\delta^{88} \mathrm{O}$ with a mean of $-5.0 \%$; from $-23.72 \%$ to $-47.6 \%$ for $\delta^{8} \mathrm{H}$ with a mean value of $-41.44 \%$. The lower mean values of $\delta^{88} \mathrm{O}$ and $\delta^{2} \mathrm{H}$ as compared to those of mean rainfall values indicate ancient water occurring in the system. This is evidenced by no tritium occurrence in all groundwater samples. Despite that, all samples cluster below the LMWL, evidencing enrichment in their stable isotope compositions with a slope of 5 (Figure 9(a)). Such a low slope can be produced by evaporation and/or mixing of groundwater and seawater [2]. In this 


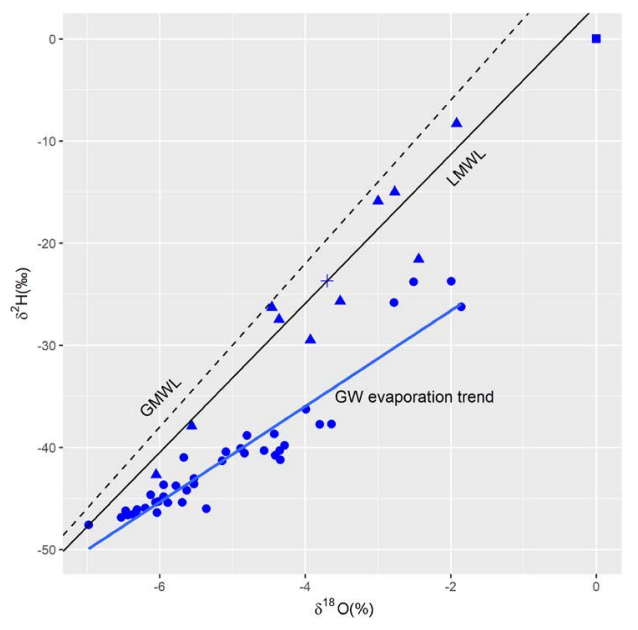

(a)

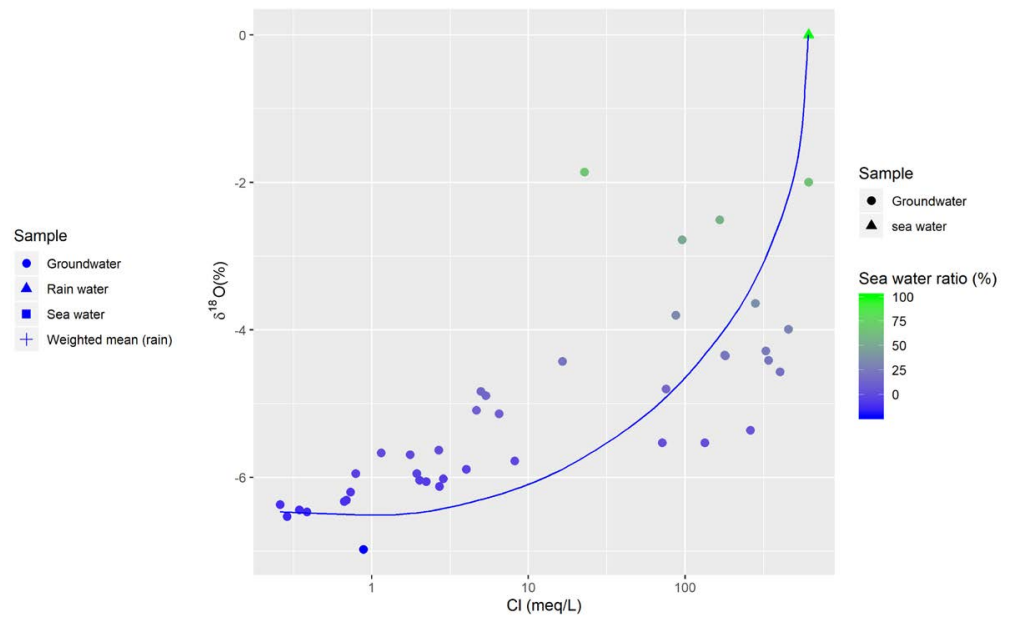

(b)

Figure 9. Stable isotopes [(a) $\delta^{2} \mathrm{H}$ vs $\delta^{18} \mathrm{O}$; (b) $\mathrm{Cl}$ vs $\left.\delta^{18} \mathrm{O}\right]$.

case, the combination of these two processes seems occurring because of the curve trend revealed by the $\mathrm{Cl}-\delta^{18} \mathrm{O}$ relationship (Figure 9(b)).

\section{Conclusions}

The main purpose of this study was to examine the salinization of groundwater in coastal area and to identify the main processes driving the groundwater mineralization. Physco-chemical parameters and isotopic contents were examined as multiple lines of evidence for geochemistry understanding of the Benichab aquifer. 1) The groundwater flow direction indicates inflow mainly from the northwest to the southeast precisely from the Atlantic Ocean toward the aquifer. This mechanism is characterized by gradual decreases in conductivity values which range from $45,200 \mu \mathrm{s} / \mathrm{cm}$ to $227 \mu \mathrm{s} / \mathrm{cm}$. 2) The hydrochemical characteristics of groundwater comprise three main types: a) fresh-groundwater, free of marine water constitutes of $\mathrm{m}-\mathrm{HCO}_{3}$ and $\mathrm{Na}-\mathrm{HCO}_{3}$ facies located in the far Est of the study area with an $\mathrm{EC}<1 \mathrm{mS} / \mathrm{cm}$; b) saline groundwater mainly of $\mathrm{Na}-\mathrm{Cl}$ facies occurring in the coastal area identified by high EC values (5 to 45.2 $\mathrm{mS} / \mathrm{cm}$ ) and $\mathrm{Cl}$ contents; and c) brackish water represented by $\mathrm{Na}-\mathrm{m}, \mathrm{m}-\mathrm{Cl}$ and mixed facies which is a mixture type between fresh water and saline water. 3) $\mathrm{Na} / \mathrm{Cl}$ and $\mathrm{Br} / \mathrm{Cl}$ ratios in saline water suggest seawater intrusion which is the main source of salinity. Seawater mixing ratios vary from $0 \%$ to $100 \%$ with a mean value of $8.42 \%$. The highest ratios are founded in the northern part of the study area where $\mathrm{Cl}$ content can exceed the value of sea water. Due to high evaporation uptake, the variation in chemical composition of groundwater demonstrates other hydrogeochemical processes, such as mineral weathering and cation exchange that are more noticeable in the freshwater group. 4) The stable isotopic composition of groundwater $\left(\delta^{18} \mathrm{O}\right.$ and $\left.\delta^{2} \mathrm{H}\right)$ to Chloride $\left(\mathrm{Cl}-\delta^{18} \mathrm{O}\right)$ indicates other process (mainly evaporation) to occur rather than a simple mixing of fresh groundwater with seawater. Despite these valuable results obtained through this 
study, further works should be carried out to infer likely recharge processes and impact of pumping in the dynamic of the system and seawater advance as well as age dating using ${ }^{3} \mathrm{H}$ and ${ }^{14} \mathrm{C}$.

\section{Acknowledgements}

The authors gratefully acknowledge Tasiast Mauritanie Limited S.A. for its financial support and the anonymous reviewers for their constructive comments and suggestions.

\section{Conflicts of Interest}

The authors declare no conflicts of interest regarding the publication of this paper.

\section{References}

[1] Colombani, N., Cuoco, E. and Mastrocicco, M. (2017) Origin and Pattern of Salinization in the Holocene Aquifer of the Southern Po Delta (NE Italy). Journal of Geochemical Exploration, 175, 1-17. https://doi.org/10.1016/j.gexplo.2017.01.011

[2] Kim, Y., Lee, K.S., Koh, D.C., Lee, D.H., Lee, S.G., Park, W.B., Koh, G.W. and Woo, N.C. (2003) Hydrogeochemical and Isotopic Evidence of Groundwater Salinization in Coastal Aquifer: A Case Study in Jeju Volcanic Island. Journal of Hydrology, 270, 282-294. https://doi.org/10.1016/S0022-1694(02)00307-4

[3] Trabelsi, R., Abid, K. and Zouari, K. (2011) Geochemistry Processes of the Djeffera Palaeogroundwater (Southeastern Tunisia). Quaternary International, 257, 43-55.

[4] Ghiglieri, G., Carletti, A. and Pittalis, D. (2012) Analysis of Salinization Processes in the Coastal Carbonate Aquifer of Porto Torres (NW Sardinia, Italy). Journal of Hydrology, 432, 43-51. https://doi.org/10.1016/j.jhydrol.2012.02.016

[5] Han, D.M., Kohfahl, C., Song, X.F., Xiao, G.Q. and Yang, J.L. (2011) Geochemical and Isotopic Evidence for Palaeo-Seawater Intrusion into the South Coast Aquifer of Laizhou Bay, China. Applied Geochemistry, 26, 863-883. https://doi.org/10.1016/j.apgeochem.2011.02.007

[6] Sola, F., Vallejos, A., Daniele, L. and Pulido-Bosch, A. (2014) Identification of a Holocene Aquifer-Lagoon System Using Hydrogeochemical Data. Quaternary Research, 82, 121-131. https://doi.org/10.1016/j.yqres.2014.04.012

[7] Cendón, D.I., Ayora, C., Pueyo, J.J., Taberner, C. and Blanc-Valleron, M.M. (2008) The Chemical and Hydrological Evolution of the Mulhouse Potash Basin (France): Are "Marine" Ancient Evaporites Always Representative of Synchronous Seawater Chemistry? Chemical Geology, 252, 109-124. https://doi.org/10.1016/j.chemgeo.2008.01.019

[8] Lucas, Y., Schmitt, A.D., Chabaux, F., Clément, A., Fritz, B., Elsass, P., et al. (2010) Geochemical Tracing and Hydrogeochemical Modelling of Water-Rock Interactions during Salinization of Alluvial Groundwater (Upper Rhine Valley, France). Applied Geochemistry, 25, 1644-1663. https://doi.org/10.1016/j.apgeochem.2010.08.013

[9] Avisar, D., Rosenthal, E., Flexer, A., Shulman, H., Ben-Avraham, Z. and Guttman, J. (2003) Salinity Sources of Kefar Uriya Wells in the Judea Group Aquifer of Israel. Part 1 Conceptual Hydrogeological Model. Journal of Hydrology, 270, 27-38. https://doi.org/10.1016/S0022-1694(02)00216-0 
[10] Ghabayen, S.M., McKee, M. and Kemblowski, M. (2006) Ionic and Isotopic Ratios for Identification of Salinity Sources and Missing Data in the Gaza Aquifer. Journal of Hydrology, 318, 360-373. https://doi.org/10.1016/j.jhydrol.2005.06.041

[11] Möller, P., Rosenthal, E., Geyer, S. and Flexer, A. (2007) Chemical Evolution of Saline Waters in the Jordan-Dead Sea Transform and in Adjoining Areas. International Journal of Earth Sciences, 96, 541-566.

https://doi.org/10.1007/s00531-006-0111-9

[12] Chamtouri, I., Abida, H., Khanfir, H. and Bouri, S. (2008) Impacts of At-Site Wastewater Disposal Systems on the Groundwater Aquifer in Arid Regions: Case of Sfax City, Southern Tunisia. Environmental Geology, 55, 1123-1133. https://doi.org/10.1007/s00254-007-1060-8

[13] Saidi, S., Bouri, S., Dhia, H.B. and Anselme, B. (2009) A GIS-Based Susceptibility Indexing Method for Irrigation and Drinking Water Management Planning: Application to Chebba-Mellouleche Aquifer, Tunisia. Agricultural Water Management, 96, 1683-1690. https://doi.org/10.1016/j.agwat.2009.07.005

[14] Merchán, D., Auqué, L.F., Acero, P., Gimeno, M.J. and Causapé, J. (2015) Geochemical Processes Controlling Water Salinization in an Irrigated Basin in Spain: Identification of Natural and Anthropogenic Influence. Science of the Total Environment, 502, 330-343. https://doi.org/10.1016/j.scitotenv.2014.09.041

[15] Perrin, J., Mascre, C., Pauwels, H. and Ahmed, S. (2011) Solute Recycling: An Emerging Threat to Groundwater Quality in Southern India? Journal of Hydrology, 398, 144-154. https://doi.org/10.1016/j.jhydrol.2010.12.024

[16] Ledesma-Ruiz, R., Pastén-Zapata, E., Parra, R., Harter, T. and Mahlknecht, J. (2015) Investigation of the Geochemical Evolution of Groundwater under Agricultural Land: A Case Study in Northeastern Mexico. Journal of Hydrology, 521, 410-423. https://doi.org/10.1016/j.jhydrol.2014.12.026

[17] Faye, S., Faye, S.C., Ndoye, S. and Faye, A. (2003) Hydrogeochemistry of the Saloum (Senegal) Superficial Coastal Aquifer. Environmental Geology, 44, 127-136. https://doi.org/10.1007/s00254-002-0749-y

[18] Richard, A., Banks, D.A., Mercadier, J., Boiron, M.-C., Cuney, M. and Cathelineau, M. (2011) An Evaporated Seawater Origin for the Ore-Forming Brines in Unconformity-Related Uranium Deposits (Athabasca Basin, Canada): $\mathrm{Cl} / \mathrm{Br}$ and $\delta^{87} \mathrm{Cl}$ Analysis of Fluid Inclusions. Geochimica et Cosmochimica Acta, 75, 2792-2810. https://doi.org/10.1016/j.gca.2011.02.026

[19] Boluda-Botella, N., Gomis-Yagües, V. and Ruiz-Beviá, F. (2008) Influence of Transport Parameters and Chemical Properties of the Sediment in Experiments to Measure Reactive Transport in Seawater Intrusion. Journal of Hydrology, 357, 29-41. https://doi.org/10.1016/j.jhydrol.2008.04.021

[20] Rao, U., Hollocher, K., Sherman, J., Eisele, I., Frunzi, M.N., Swatkoski, S.J. and Hammons, A.L. (2005) The Use of $36 \mathrm{Cl}$ and Chloride/Bromide Ratios in Discerning Salinity Sources and Fluid Mixing Patterns: A Case Study at Saratoga Springs. Chemical Geology, 222, 94-111. https://doi.org/10.1016/j.chemgeo.2005.06.011

[21] Jørgensen, N.O., Andersen, M.S. and Engesgaard, P. (2008) Investigation of a Dynamic Seawater Intrusion Event Using Strontium Isotopes (87Sr/86Sr). Journal of Hydrology, 348, 257-269. https://doi.org/10.1016/j.jhydrol.2007.10.001

[22] Elouard, P. and Millot, G. (1959) Observations sur les silicifications du Lutétien en Mauritanie et dans la vallée du Sénégal par P. Elouard et G. Millot. Sciences Géologiques, bulletins et mémoires, 12, 15-19. https://doi.org/10.3406/sgeol.1959.1194 
[23] Caruba, R. and Dars, R. (1991) Géologie de la Mauritanie. Université de Nice-Sophia Antipolis, $321 \mathrm{p}$.

[24] Mohamed, A.S. (2012) Aproche hydrodynamique et géochimique de la recharge de la nappe du Trarza, sud-ouest de la Mauritanie (These de doctorat). Université Paris Sud, Paris.

[25] Certain, R., Dia, A., Aleman, N., Robin, N., Vernet, R., Barusseau, J.P. and Raynal, O. (2018) New Evidence of Relative Sea-Level Stability during the Post-6000 Holocene on the Banc d'Arguin (Mauritania). Marine Geology, 395, 331-345. https://doi.org/10.1016/j.margeo.2017.11.007

[26] Ould Sabar, M.S. (2001) Structure, mecanisme et projet d'aménagement futur de la Sebkha Ndghamcha (Mauritanie). These de doctorat, Universite de Nice Sophia Antipolis, $169 \mathrm{p}$.

[27] Piper, A.M. (1944) A Graphic Procedure in the Geochemical Interpretation of Water Analyses. American Geophysical Union Transactions, 25, 914-923. https://doi.org/10.1029/TR025i006p00914

[28] Faye, S., Maloszewski, P., Stichler, W., Trimborn, P., Faye, S.C. and Gaye, C.B. (2005) Groundwater Salinization in the Saloum (Senegal) Delta Aquifer: Minor Elements and Isotopic Indicators. Science of the Total Environment, 343, 243-259. https://doi.org/10.1016/j.scitotenv.2004.10.001

[29] Abu-alnaeem, M.F., Yusoff, I., Ng, T.F., Alias, Y. and Raksmey, M. (2018) Assessment of Groundwater Salinity and Quality in Gaza Coastal Aquifer, Gaza Strip, Palestine: An Integrated Statistical, Geostatistical and Hydrogeochemical Approaches Study. Science of the Total Environment, 615, 972-989.

https://doi.org/10.1016/j.scitotenv.2017.09.320

[30] Todd, D.K. (1959) Ground Water Hydrology. John Wiley and Sons Inc., New York, 277-294.

[31] Chaudhuri, S. and Ale, S. (2014) Long Term (1960-2010) Trends in Groundwater Contamination and Salinization in the Ogallala Aquifer in Texas. Journal of $\mathrm{Hy}$ drology, 513, 376-390. https://doi.org/10.1016/j.jhydrol.2014.03.033

[32] Khairy, H. and Janardhana, M. (2013) Hydrogeochemical Features of Ground-Water of Semi-Confined Coastal Aquifer in Amol-Ghaemshahr Plain, Mazandaran Province, Northern Iran. Environmental Monitoring and Assessment, 185, 9237-9264. https://doi.org/10.1007/s10661-013-3248-6

[33] Nasher, G., Al-Sayyaghi, A. and Al-Matary, A. (2013) Identification and Evaluation of the Hydrogeochemical Processes of the Lower Part of Wadi Siham Catchment Area, Tihama Plain, Yemen. Arabian Journal of Geosciences, 6, 2131-2146. https://doi.org/10.1007/s12517-011-0471-8

[34] Fisher, R.S. and Mullican III, W.F. (1997) Hydrochemical Evolution of Sodium-Sulfate and Sodium-Chloride Groundwater beneath the Northern Chihuahuan Desert, Trans-Pecos, Texas, USA. Hydrogeology Journal, 5, 4-16. https://doi.org/10.1007/s100400050102

[35] Re, V., Sacchi, E., Martin-Bordes, J.L., Aureli, A., El Hamouti, N., Bouchnan, R. and Zuppi, G.M. (2013) Processes Affecting Groundwater Quality in Arid Zones: The Case of the Bou-Areg Coastal Aquifer (North Morocco). Applied Geochemistry, 34, 181-198. https://doi.org/10.1016/j.apgeochem.2013.03.011

[36] Andreasen, D.C. and Fleck, W.B. (1997) Use of Bromide: Chloride Ratios to Differentiate Potential Sources of Chloride in a Shallow, Unconfined Aquifer Affected by Brackish-Water Intrusion. Hydrogeology Journal, 5, 17-26.

https://doi.org/10.1007/s100400050104 
[37] Hem, J.D. (1985) Study and Interpretation of the Chemical Characteristics of Natural Water (Vol. 2254). Department of the Interior, US Geological Survey.

[38] Custodio, E. and Bruggeman, G.A. (1987) Groundwater Problems in Coastal Areas. Studies and Reports in Hydrology. UNESCO, Paris.

[39] Appelo, C.A.J. and Postma, D. (2005) Geochemistry, Groundwater and Pollution. Second Edition, Balkema, Rotterdam, 656 p. https://doi.org/10.1201/9781439833544

[40] Tricart, J. (1961) Notice explicative de la carte géomorphologique du delta du Sénégal (No. 8). Editions Technip.

[41] Illy, P. (1973) Étude hydrogéologique de la vallée du fleuve Sénégal. Projet hydro agricole du bassin du fleuve Sénégal, (65061), 163.

[42] AC00442214, A. (1992) Statistical Treatment of Data on Environmental Isotopes in Precipitation. International Atomic Energy Agency, Wien.

[43] Craig, H. (1961) Standard for Reporting Concentrations of Deuterium and Oxygen18 in Natural Waters. Science, 133, 1833-1834.

https://doi.org/10.1126/science.133.3467.1833 